\title{
Factors Influencing Adoption of Online Payment via E-Commerce Platforms
}

\author{
Ha Thu Luong (Corresponding author) \\ School of Advanced Educational Programs, National Economics University, Hanoi, Vietnam \\ 207 Giai Phong Street, Hai Ba Trung District, Hanoi 100000, Vietnam \\ Tel: $(+84) 903001888$ \\ Email: haluongthu@neu.edu.vn \\ My Tra Le \\ School of Advanced Education Programs, National Economics University, Hanoi, Vietnam \\ Hang Buom Ward, Hoan Kiem District, Ha Noi 100000, Viet Nam \\ Tel: $(+84) 971518624$ \\ Email: lemy7712@gmail.com \\ Quan Hong Pham \\ School of Advanced Education Programs, National Economics University, Hanoi, Vietnam \\ Minh Khai Ward, Hai Ba Trung Distrct, Hanoi 100000, Vietnam \\ Tel: (+84) 946569859 \\ Email: quan31032@gmail.com
}

\begin{abstract}
In this study, the research group applied the Technology Acceptance Model (TAM) by Davis (1989) to analyze factors influencing customers' intention to use the online payment via e-commerce platforms as well as to encourage Vietnamese consumers to adapt this means of payment. Besides Perceived Ease of Use and Perceived Usefulness in the original model of Davis (1989), three additional dependent factors (Subjective Norm, Trust, Risk) were added to the model. The new model proposed by the research group aims to give a more well-rounded explanation on Vietnamese consumers' attitude and intention towards the online payment. Using sample data including 448 consumers in the Northern region of Vietnam, the research group has been able to validate the hypothesis model and prove that independent and dependent variables (Attitude towards Use and Intention to Use) are positively correlated. Among the 5 dependent variables, Subjective Norm is found to be the most significant factor contributing to promote online payment attitude and intention through e-commerce websites of Vietnamese consumers.
\end{abstract}

Keywords: TAM, online payment, online shopping, e-commerce

DOI: $10.7176 / \mathrm{EJBM} / 13-8-19$

Publication date: April 30th 2021

\section{Introduction}

Nowadays, people are living and working in a digital economy. The advent of digitalization has changed many fields as well as made significant contributions to people's life, society and the structure of the economy. In which, the two most important contributions are e-commerce - platforms for traditional businesses to switch to online businesses, and online payment.

In Vietnam, e-commerce sales have maintained a rapid growth rate, while online payment via ecommerce platforms is not widely utilized by consumers because of their attitude and preconception toward this form of payment. Statistics show that cash still dominates with nearly $80 \%$ of e-commerce transactions, meaning that the proportion of non-cash payments only accounts for more than $20 \%$, lower than the target set by the Vietnamese Government in 2020. The report of the World Bank (WB) also commented: "Vietnam's performance in terms of boosting the digital economy is comparable to that of Eastern countries in South Asia, except for payments". The situation in question is one of the biggest problems impeding the development of the e-commerce platform in Vietnam. Thus, to promote this platform and to maintain the digitization of the economy in the 4.0 
Industrial Revolution, related parties need to take part in innovating consumers' awareness and providing reliable online payment services.

Besides applying the TAM theoretical model, the research uses the new variable Subjective Norm to analyze the influence of social pressure on the attitude and intention to use online payment. Risk and Trust were also added as we believe that customers' perceived risk and trust in a platform are closely linked with their behavior while doing online transactions.

With the proposed model, the research suggests solutions for e-commerce platforms and online businesses to develop policies that encourage users to adapt online payment - A trend in the 4.0 Industrial Revolution. Additionally, the research contributes to change the opinion and attitude of Vietnamese consumers by raising awareness about online payment because of the benefits and usefulness that this method brings.

\section{Literature Review and Theoretical Framework}

\subsection{Literature Review}

Technology Acceptance Model (TAM) is one of the most used models to map user acceptance of new technologies in different settings. Several researchers have included and further developed the two TAM constructs into their studies. Padilla-Meléndez, del Aguila-Obra and Garrido-Moreno (2013) discussed the gender differences in technology acceptance, and although differences have often regarded as small, males seem to be more agile in technology usage compared to females in different situations (Van Braak, 2004; SanchezFranco, 2006; Ong \& Lai, 2006). TAM constructs are also studied to ascertain customers' acceptance of online banking and their satisfaction (Adamson and Shine, 2003; Chau and Lai, 2003; Pikkarainen et al., 2004). In 2009, a study by Ha and Stoel used TAM to investigate the intention to shop online that leads to the use of e-payment. In other researches, Perceived Ease of Use and Perceived Usefulness were conceptually extended to have an in-depth understanding of electronic communication (Karahanna and Straub, 1999; Gefen and Straub, 1997). It has also combined with consumer behavior, and psychology constructs to study online commerce (Koufaris, 2002).

\subsection{Theoretical Framework}

The Technology Acceptance Model (TAM), which was first introduced by Fred Davis in 1989, is a theoretical model derived from The Theory of Reasoned Action (TRA) (Fishbein \& Ajzen, 1975). The TRA model is a general model with the main purpose is to understand an individual's voluntary behavior by examining the underlying basic motivation to perform an action. According to Ajzen and Fishbein, TRA proposes that consumer's actual behavior can, whether be performed or not, is determined by their intention to use, which is both influenced by attitude to use and subjective norms towards the behavior.

Technology Acceptance Model (TAM) explains how users come to accept and use technology (Davis, 1989). The origin TAM constructs consisted of Perceived Ease of Use (PE) and Perceived Usefulness (PU). Both of these constructs will ultimately determine the Attitude towards Use (AT), Behavioral Intention to Use (BI), and Actual System Use (AU) (Davis, Bagozzi and Warshaw, 1989). With this model, Davis claims that the new technology might be too complex for consumers to know at first. Therefore, consumers will have attitudes as well as intentions to learn how to use the new technology before having efforts to actually use it. Because attitude and intention to use might not be clear from the beginning, the actual use could not be the direct results from it.

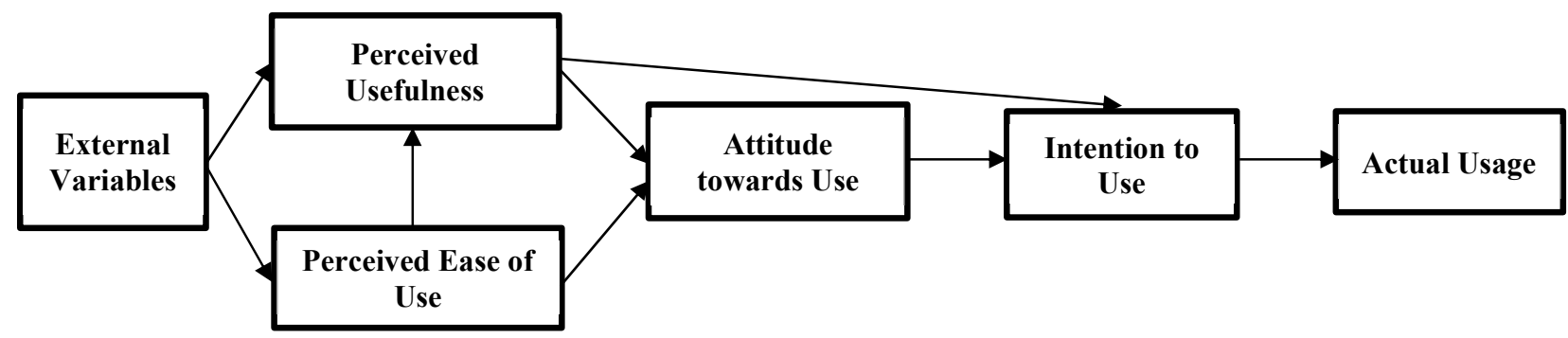

Figure 1. Technology Acceptance Model - Davis, 1989

\subsection{E-commerce and online payment trends}

E-commerce is gradually growing and evolving, which changes the traditional business activities as well as our daily life. Over the past decade, the global e-commerce platforms have expanded at an average rate of $20 \%$ a year as the traditional physical stores are shrinking. In the future, e-commerce is likely to move further since there are more and more customers and businesses starting to adopt it. For customers, shopping through e- 
commerce floors helps saving time and effort, also bringing the diversity of choices in terms of shopping items. For businesses, many of them have carried out digital transformation, conducting online sales on e-commerce floors as they realize that this form of sales helps reduce costs and save resources compared to selling in traditional stores. Moreover, under the impact of the Covid-19 pandemic, many stores are required to close and people are asked to only go out for actual needs. Therefore, both businesses and consumers tend to start using online platforms which are the e-commerce floors for shopping demands.

In the context of the growing economy, because the cash payment is no longer satisfy payment needs, having a new and more convenient form of payment is requirable and that is the online payment. Online payment is one of the most important parts as well as developing focus of e-commerce. This kind of payment meets the needs in serving customers as it helps saving costs and opening potential opportunities for businesses. Nowadays, online payment is being world-widely used in many developed countries such as China, Korea, Singapore, Malaysia, Brazil, India, etc. According to World Bank's survey (WB), online payment has become a popular payment method in many developed countries, with the spending value of users accounting for more than $90 \%$ of total daily transactions. Additionally, in Vietnam these recent years, online payment is also growing rapidly, bringing many advantages such as reducing transaction time, increasing convenience and safety for consumers, etc. Statistics in 2020 shows that Vietnam is in the global economic trend as the Internet accounts for nearly $60 \%$ of the population and $33 \%$ of Vietnamese consumers use online payment when shopping online. It can be seen that online payment in Vietnam is developing strongly, with the competition of non-credit retail services by commercial banks, technology companies and payment intermediary organizations.

\section{Hypothesis development and research model}

\subsection{Hypothesis development}

Perceived Usefulness: Usefulness is supposed to be able to enhance a person's job performance by leveraging and utilizing the advantages of a particular system (Davis, 1989; Lin and Nguyen, 2011). This factor is considered to be one of the most important factors in explaining attitude towards use along with the adoption of the system. This study will define perceived usefulness as features of products and services that help users save resources, make the process of online payment easier and more efficient to use than traditional services. This will eventually lead to attitude towards use. In another study, it was mentioned that perceived usefulness has a significant and positive influence on consumers' attitudes toward shopping at online stores (Delafrooz et al., 2011). For the above arguments, our research group formally hypothesize that:

\section{H1: "Perceived Usefulness" has a positive impact on Attitude towards Use.}

Perceived Ease of Use: Perceived ease of use is defined as "the degree to which one believes that using a particular system will be effortless" (Davis, 1989). Similar to perceived usefulness, perceived ease of use is another important factor for technology adoption. However, Pikkarainen et al (2004) also argue that perceived ease of use influences technology adoption more than perceived usefulness. Moreover, Pavlou (2003) declared that perceived ease of use is a major factor in accepting the attitude of consumers in online stores. Likewise, perceived ease of use has been shown to have a strong impact on customers' attitude when shopping in online stores (Palvia, 2009). Collaborating the above arguments and evidence, our group formally develop the following hypothesis:

\section{H2: “Perceived Ease of Use” has a positive impact on Attitude towards Use.}

Subjective norm: Venkatesh and Davis (2000) reported that subjective norm is a measurement for social pressure that affect consumers before they make a decision to perform a behavior. This key term is referred to social influence, indicating beliefs of a person whether or not he or she should engage in the behavior under peers and important people evaluation (Ajzen, 1991). Khalil and Michael, (2008) considered friends, family members and colleagues as subjective norms that have a positive influence on individuals to purchase online. It can be said that the more positive reviews from the reference group are, the higher the attitude toward using the product is. The rationale leads to the third hypothesis tested in this research:

\section{H3: "Subjective norm" has a positive impact on Attitude towards Use.}

Trust: From the client's point of view, trust is defined as "the psychological state that leads to a client's willingness to transact over the Internet and a desire for a payment platform to do its job, regardless of the client's willingness to transact over the Internet (Mayer, Davis and Schoorman, 1995). In other research articles, trust is also considered as one of the factors affecting attitude and intention of customers to use. Specifically, the study of Hoda Mashayekhi and Yoosof Mashayekhi (2017) has determined the effect of the factor "Trust" on intention to 
use online payment is positive. Furthermore, the consumer's decision to use a system is based on a personal assessment of the system's trustworthiness. According to Ha and Stoel (2009), attitude towards shopping was influenced by trust. Thus, the present study illustrated below hypothesis:

\section{H4: “Trust" has a positive impact on Attitude towards Use.}

Risk: According to Aw, Ab Hamid and Eaw (2011), risk is defined as the uncertainty associated with a consumer's action that could lead to certain outcomes or consequences. Perceived risk and trust are closely linked when doing online transactions, as indicated by Featherman and Pavlov (2003) that the level of risk would decrease if customers trust parties involved in the transactions. On the other hand, risk could be the mediation of trust and willingness to purchase online (Jarvenpaa, Tractinsky, and Vitale, 2000). Moreover, risk is also very important determining factors that influence the attitude of shopping consumers online shopping (Shu-Hung \& Bayarsaikhan, 2012). Meanwhile, another study cited by Hsu et al. (2014) rísk forms the attitude of consumers to shop online that needs to be considered because of the decision of consumers shopping online because there is also an online store fraud and other events that harm consumers online stores. Synthesis of the findings of these authors gives rise to the hypothesis:

\section{H5: “Risk" has a positive impact on Attitude towards Use.}

Attitude towards Use and Intention to Use: Suleman et al. (2019) and Hsu et al. (2014) defined attitude as the level of positive feelings of consumers about participating in shopping and it is agreed that this positive attitude opens up more opportunities for consumers to choose where to shop. The propensity to learn to behave consistently in a beneficial or unfavorable manner with respect to a given object is defined as attitude (Schiffman et al., 2010). And, according to previous studies, attitudes are greatly linked to decisions in a positive way (Wu \& Chen, 2014; Lee, 2016). Additionally, many researchers had examined the relation between attitude towards use and intention to use. It is widely believed that attitude towards use is an intermediary factor affecting intention to use. In details, one of the most striking features in the Technology Acceptance Model - Davis (1989) lies on the major impact of attitude to intention. According to Ajzen (1991), intention is a motivating factor, it motivates an individual to be willing to perform acts and intentions are directly affected by attitudes, subjective norm and perceived behavioral control. The more active the attitude towards use is, the higher intention to do the act. Therefore, the last hypothesis is as follows:

\section{H6: “Attitude towards Use” has a positive impact on Intention to Use.}

\subsection{Research model}

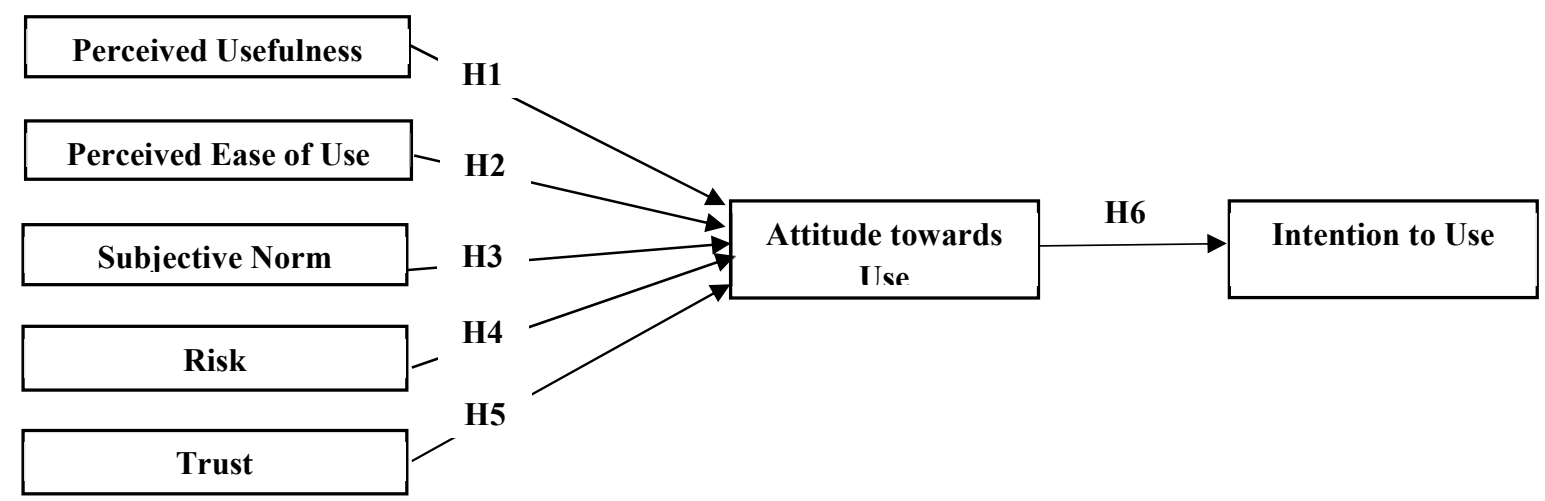

Figure 2. Model of factors affecting Vietnamese' online payment intention when transacting through e-commerce platforms

Based on the theoretical framework and summary of previous literature, our research model of factors affecting online payment intention when transacting through e-commerce platforms in Vietnam is illustrated in Figure 2. Along with defined factors, six hypotheses were constructed to examine impact of independent variables (perceived usefulness, perceived ease of use, subjective norm, trust, risk) to dependent variables (attitude towards use and intention to use). 


\section{Data Analysis and Research Results}

\subsection{Measure reliability}

The team first tested the reliability of 7 potential variables, including 5 independent factors and two dependent ones with 36 items in total by using Cronbach's Alpha. Potential variables are considered reliable if the value of Cronbach's Alpha coefficient of that variable is not less than 0.6 (Hoang Trong \& Chu Nguyen Mong Ngoc, 2008) and the value of the corrected item - total correlation of each item in considered potential variables greater than or equal to 0.3 (Nunnaly, J., 1978). After running the test, the group obtained results that meet the above two requirements with all potential variables have Cronbach's Alpha values range from 0.842 to 0.897 and all items have corrected item- total correlation values greater than 0.3 . The analytical results of the scale reliability are shown in Table 1.

Table 1. Reliability analysis results

\begin{tabular}{|c|l|c|c|c|c|}
\hline \multirow{2}{*}{$\begin{array}{c}\text { Factor } \\
\text { Code }\end{array}$} & \multirow{2}{*}{ Factor's name } & \multicolumn{2}{|c|}{$\begin{array}{c}\text { Number of observed } \\
\text { items }\end{array}$} & \multirow{2}{*}{$\begin{array}{c}\text { Cronbach' } \\
\text { s Alpha }\end{array}$} & $\begin{array}{c}\text { Corrected Item - } \\
\text { Total Correlation } \\
\text { minimum }\end{array}$ \\
\cline { 3 - 4 } & & Before & After & & 0.321 \\
\hline $\mathrm{PU}$ & Perceived Usefulness & 5 & 3 & 0.604 & 0.561 \\
\hline $\mathrm{PE}$ & Perceived Ease of Use & 6 & 6 & 0.860 & 0.650 \\
\hline $\mathrm{SN}$ & Subjective Norm & 5 & 5 & 0.858 & 0.678 \\
\hline $\mathrm{Tr}$ & Trust & 5 & 5 & 0.874 & 0.629 \\
\hline $\mathrm{Ri}$ & Risk & 5 & 5 & 0.851 & 0.649 \\
\hline $\mathrm{AT}$ & Attitude & 5 & 5 & 0.886 & 0.553 \\
\hline $\mathrm{IN}$ & Intention & 5 & 5 & 0.845 & \\
\hline
\end{tabular}

(Source: Quantitative research results)

\subsection{Measure validity}

The research team continued to conduct the exploratory factor analysis (EFA) by using Principle Components extraction method with Varimax rotation. First of all, the group ran EFA for the first time with variables Perceived Ease of use, Subjective Norm, Perceived Usefulness, Risk and Trust. The results of the first EFA analysis, KMO test $=0.9$, Barlett's test with Sig. $=0.000,5$ factors with Eigenvalue values $\geq 1$ and no items were rejected due to the loading factor values of the items are all greater than 0.5 (Hair et al., 2014). The group conducted the second EFA test with the remaining two variables: Attitude towards use and Intention to use. The results showed that there is a difference between Attitude and Intention, KMO test result $=0.913$, Barlett's test has Sig. $=0.000$, there are 2 factors with Eigenvalue value $\geq 1$ and items are greater than 0.5 . From here, the team created 3 independent variables and 2 dependent variables to serve the regression analysis. Exploratory Factor Analysis results are shown in Appendix 1.

\subsection{Hypothesis testing}

After performing two exploratory factor analyses, the research group identified 7 variables serving the running of regression models instead of the potential variables which were initially assumed. Specifically, the model will include such independent variables as Perceived Usefulness (PU), Perceived Ease of use (PE), Subjective Norms (SN), Trust (Tr), Risk (Ri), and two dependent variables are Attitude towards usage (AT) and Intention to use (IN). The group expected to run two regression models, in which the first model studies the impact of 3 independent variables on the Attitude towards Use (AT) and the second model assesses the impact of the AT on Intention to use (IN). Our research group then ran the first regression model to analyze the impact of three independent variables on Attitude towards use (AT). As a result, the coefficient of R2 is 0.372 indicates that the built regression model is consistent with the data set at $37.2 \%$, there is no collinearity phenomenon between variables due to the fact that VIFs are below 2, F-test has a low Sig. value $(=0.000 \mathrm{~b})$. Next, the group ran a second regression model with two variables Attitude towards usage (AT) and Intention to use (IN). The results obtained the adjusted R2 at 0.45 , F-test has a low Sig. value $(=0.000 \mathrm{~b})$. Results of two specific regression models are indicated in Table 2. 
Table 2. Regression results

\begin{tabular}{|c|c|c|c|c|c|c|c|c|}
\hline & Model & $\begin{array}{l}\text { Unsta } \\
\text { d Coe }\end{array}$ & $\begin{array}{l}\text { lardize } \\
\text { icients }\end{array}$ & $\begin{array}{c}\text { Standardize } \\
\text { d }\end{array}$ & $\mathbf{T}$ & Sig. & $\begin{array}{l}\text { Colli } \\
\text { y Sta }\end{array}$ & $\begin{array}{l}\text { earit } \\
\text { istics }\end{array}$ \\
\hline & (Constant) & 0.073 & 0.291 & & 0.252 & 0.801 & & \\
\hline & PU & 0.218 & 0.051 & 0.179 & 4.269 & 0.000 & $\begin{array}{c}0.79 \\
8\end{array}$ & $\begin{array}{c}1.25 \\
3\end{array}$ \\
\hline & PE & 0.253 & 0.062 & 0.188 & 4.063 & 0.000 & $\begin{array}{c}0.65 \\
4\end{array}$ & $\begin{array}{c}1.33 \\
4\end{array}$ \\
\hline 1 & $\mathrm{SN}$ & 0.323 & 0.040 & 0.347 & 8.041 & 0.000 & $\begin{array}{c}0.75 \\
4\end{array}$ & $\begin{array}{c}1.32 \\
6\end{array}$ \\
\hline & $\operatorname{Tr}$ & 0.062 & 0.050 & 0.054 & 1.252 & 0.211 & $\begin{array}{c}0.75 \\
0\end{array}$ & $\begin{array}{c}1.33 \\
4\end{array}$ \\
\hline & $\mathrm{Ri}$ & 0.137 & 0.051 & 0.106 & 2.692 & 0.007 & $\begin{array}{c}0.91 \\
5\end{array}$ & $\begin{array}{c}1.09 \\
3\end{array}$ \\
\hline De & able: AT - & vards I & age & & & & & \\
\hline ? & (Constant) & 1.351 & 0.128 & & $\begin{array}{c}10.85 \\
7\end{array}$ & 0.000 & & \\
\hline 2 & AT & 0.652 & 0.032 & 0.699 & $\begin{array}{c}20.26 \\
3\end{array}$ & 0.000 & $\begin{array}{c}1.00 \\
0\end{array}$ & $\begin{array}{c}1.00 \\
0\end{array}$ \\
\hline
\end{tabular}

(Source: Quantitative research results)

The research group obtained two regression models that analyze the impact of independent variables on dependent variables as follows:

$$
\begin{array}{ll}
\text { Model 1: } & \mathrm{AT}=0.179(\mathrm{PU})+0.188(\mathrm{PE})+0.347(\mathrm{SN})+0.106(\mathrm{Ri}) \\
\text { Model 2: } & \mathrm{IN}=0.699(\mathrm{AT})
\end{array}
$$

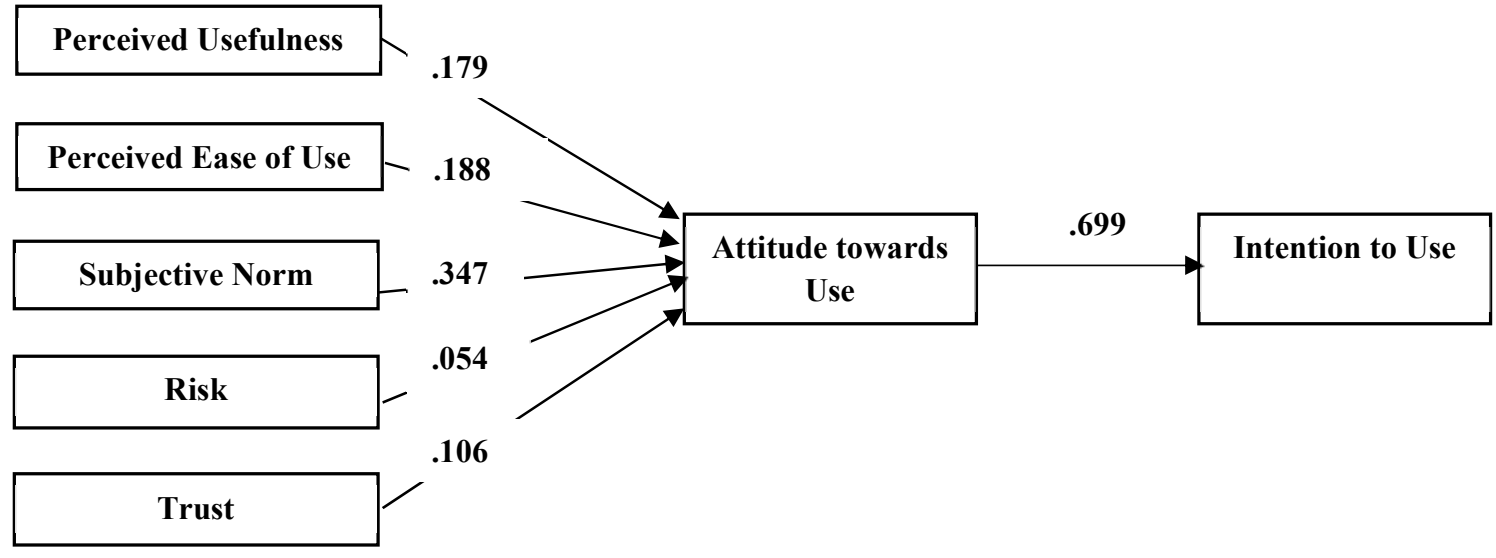

Figure 3. Research result - Factors affecting online payment intention when transacting through e-commerce platforms in Vietnam

With the significance level of 5\%, 4 out of 5 independent variables in the two models are significant, except the variable Trust (Tr) with its Sig. exceeds 0.05. In model (1), Perceived Usefulness (PU), Perceived Ease 
of Use (PE), Subjective Norm (SN), Risk (Ri), all have positive effects on the Attitude towards use (AT). In particular, Subjective Norm is considered to have the strongest impact $(\beta=0.347)$. This is followed by Perceived Ease of use (PE), Perceived (PU) and finally Risk (Ri). In model (2), the variable Attitude towards use (AT) is significant and is assessed to have a positive impact on the Intention to use (IN).

\section{Conclusion, Recommendations, Limitations and Further research directions \\ 5.1. Conclusion}

Research shows that the independent variables Perceived Ease of Use (PE), Perceived Usefulness (PU), Subjective Norms (SN), and Risk (Ri) all influence Attitude (AT) towards the use of online payment when purchasing on ecommerce websites, among them are the two most powerful variables PU and SN. Thus, Subjective Norms (SN) or the influence of reference groups is a characteristic factor affecting consumers' choice of online payment when shopping on e-commerce sites. At the same time, research also shows that Attitude (AT) has a strong impact on Intention to use online payments (IN). This implies that when consumers make purchases on ecommerce platforms, if they have a positive attitude towards the online payment, they will have the intention of using online payment.

\subsection{Recommendation For e-commerce platforms}

Many e-commerce platforms nowadays operate as wholesalers, which means that these businesses will import products manufactured by producers, ranging from famous brands to well-known publishers, to sell them on their websites. Evidently, with the emergence of this kind of retailer, customers won't have to go shopping at the brick-and-mortar stores that they used to do in the past. Instead, they can easily make purchases on e-commerce websites with just a few simple mouse-clicks. E-commerce businesses are recommended to spend resources to improve their interfaces, which certainly makes their websites more user-friendly and easier to access, thus encouraging more customers to switch to online shopping. When at a crossroads of choosing payment methods, consumers tend to use traditional methods in which they will pay by cash after receiving the goods delivered to their houses. However, this can be changed if e-commerce websites adopt online payment that are as simple as paying by cash. In fact, they should implement methods that people would feel at ease when using. Consumers are likely to make online payments if procedures of an online method are not complicated and do not require shoppers to spend a large amount of time learning how to familiarize themselves with these steps.

Besides, some consumers make online purchases on e-commerce websites because of the benefits that these businesses bring, one of which is the privileges related to online payment. Paying online is believed to save consumers' resources in terms of time, efforts and sometimes allows customers to carry out more online transactions simultaneously. Evidently, it is the obligation of e-commerce platforms to make their shoppers realize the usefulness they would receive when making online payment and they can manage to do it through the help of media tools.

Consumers' decisions on choosing online payment seem to be affected by the surrounding people. This implies that consumers tend to consult others about using online payment before making the choice for themselves. E-commerce websites, as a result, need to identify who these reference groups are and the level of impact these groups can exert on customers. Even in some cases, e-commerce trading floors may encourage reference groups to use online payment first, then these people can tell others about using this kind of payment method via wordof-mouth or reviews posted on social network websites. The reviews of reference groups are very valuable as they provide e-commerce websites a chance to evaluate the effectiveness of online payment forms they are implementing so that e-commerce businesses can make necessary adjustments.

\section{For companies doing businesses on e-commerce websites}

Some e-commerce platforms serve as a middleman that connect customers to sellers. They create space for sellers to set up online shops on e-commerce sites. This means that when consumers type a brand name or a shop name in the search box, they will be immediately taken to the shop's site where it displays a wide range of products offered by this shop. Companies that sell their goods on e-commerce websites are also encouraged to accept any form of online payment that brings a high level of satisfaction to customers in terms of ease of use and usefulness. Moreover, transactions-related risks should also be taken seriously by companies before they officially implement an online payment as consumers are very concerned about potential risks that they may encounter when paying online. 
Like e-commerce platforms, companies that operate on e-commerce sites should take the reference groups into account since these groups' opinions may affect customers' attitudes and intentions to use online payment. More emphasis should be put on figuring out who these reference groups are as well, then each company can evaluate the influence of these groups on customers' decision-making process. It is obvious that nowadays people are triggered to purchase merchandise either online or offline, not only by their friends or family members but also because of the advertising campaigns. Some of these campaigns may have celebrities such as famous singers or successful athletes to promote products of famous brands in order to attract customers who are fans of these influencers. This technique is often called celebrity endorsement. Sellers on e-commerce trading floors of course can apply this technique to promote the use of available online payment besides current products.

\section{For consumers}

Consumers should consider changing to online payment whenever they shop on e-commerce websites as paying online is becoming a modern consumption trend in the era of digital economy. Only by selecting this method of payment, do customers realize the benefits it brings as well as how easy it is to conduct an online payment transaction. Since there are numerous forms of online payment, customers are encouraged to choose the ones that come with a high level of security. Once getting used to it, individuals can recommend online payment to other people who also regularly purchase on e-commerce websites by using word-of-mouth or posting their reviews on rating websites. These reviews in turn can be a great source of reference for others to consult.

\subsection{Limitations and Further Research Directions}

The scope of this study is in Hanoi - a major city in Vietnam, so these conclusions can be partial. This big city is at the forefront of using online payment through e-commerce floors and the people in this area have higher living standards. Because Vietnam's geography is quite complicated, so for further research, researchers need to increase the size of the study, such as other groups of the population.

\section{References in English}

Adamson, I., \& Shine, J. (2003), Extending the New Technology Acceptance Model to Measure the End User Information Systems Satisfaction in a Mandatory Environment: A Bank's Treasury, Technology Analysis \& Strategic Management, Vol. 15 No. 4, 441-455.

Aw, Ab Hamid and Eaw (2011), Risk perception of the E-payment systems: a young adult perspective.

Chau \& Lai (2003), An empirical investigation of the determinants of user acceptance of Internet banking.

Delafrooz, N., Paim, L.H., \& Khatibi, A. (2011), Understanding consumer's internet purchase intention in Malaysia, African Journal of Business Management, 5(3), 2837-2846.

Featherman, M.S. \& Pavlou, P.A. (2003), "Predicting e-services adoption: a perceived risk facets perspective", International Journal of Human-Computer Studies, Vol. 59, No. 4, pp.451-474, https://doi.org/10.1016/S10715819(03)00111-3.

Gefen, D. \& Straub, D. (1997), Gender differences in the Perception and Use of E-mail: An extension of the Technology Acceptance Model.

Ha, S. \& Stoel, L. (2009), Consumer e-shopping acceptance: Antecedents in a technology acceptance model, Journal of Business Research, 62 (5), pp.565-571.

Hoda Mashayekhi \& Yoosof Mashayekhi (2017), Factors influencing adoption of e-payment systems: an empirical study on Iranian customers.

Hsu, M.H., Chuang, L.W., \& Hsu, C.S. (2014), Understanding online shopping intention: the roles of four types of trust and their antecedents, Internet Research, 24(3), 332-352.

Jarvenpaa, Tractinsky, \& Vitale (2000), Consumer trust in an Internet Store, Journal of Internet Commerce, Vol. 7(1) 29-73. 
Karahanna, E. \& Straub, D. (1999), The psychological origins of perceived usefulness and ease of use, Information \& Manager.

Khalil Md Nor \& Michael Pearson (2008), An Exploratory Study Into the Adoption of Internet Banking in a Developing Country: Malaysia.

Koufaris, M. (2002), Applying the Technology Acceptance Model and Flow Theory to Online Consumer Behavior.

Lee, H. (2016), Examining neighborhood influences on leisure-time walking in older Korean adults using an extended Theory of Planned Behavior, Landscape and Urban Planning, 148, 51-60, New Jersey: Pearson Education Limited.

Lin, C \& Nguyen, C.H. (2011), Exploring e-payment adoption in Vietnam and Taiwan, Journal of Computer Information System, pp.41-52.

Mayer, R., Davis, J. \& Schoorman, F. (1995), An integrative model of organizational trust, Academy of Management Review, 20 (3), pp.709-734.

Nunnally, J. (1978), Psychometric Theory, New York, McGraw-Hill.

Ong, C., \& Lai, J. (2006), Gender differences in perceptions and relationships among dominants of e-learning acceptance, Computers In Human Behavior, 22(5), 816-829.

Özkan, S., Bindusara, G. \& Hackney, R. (2010), Facilitating the adoption of e-payment systems: theoretical constructs and empirical analysis, Journal of Ent Info Management, 23 (3), pp.305-325.

Padilla-Meléndez, A., del Aguila-Obra, A., \& Garrido-Moreno, A. (2013), Perceived playfulness, gender differences and technology acceptance model in a blended learning scenario, Computers \& Education, pp.63, 306-317.

Palvia, P. (2009), The role of trust in e-commerce relational exchange: A unified model, Information \& Management, 213-220.

Pavlou, P. A. (2003), Consumer Acceptance of Electronic Commerce: Integrating Trust and Risk with the Technology Acceptance Model, International Journal of Electronic Commerce, 7(3), 101-134.

Pikkarainen et al (2004), Consumer acceptance of online banking: An extension of Technology Acceptance Model.

Pikkarainen, T., Pikkarainen, K., Karjaaluoto, H. \& Pahnila, S. (2004), Consumer acceptance of online banking: an extension of the technology acceptance model.

Sánchez-Franco, M. (2006), Exploring the influence of gender on the web usage via partial least squares, Behaviour \& Information Technology, 25(1), 19-36.

Schiffman, L., Kanuk, L., Wisenblit, J. (2010), Consumer behavior, 10th edition, New Jersey: Pearson Prentice Hall.

Shu-Hung, H.S., \& Bayarsaikhan, B.E. (2012), Factors Influencing on Online Shopping Attitude and Intention of Mongolian Consumers, The Journal of International Management Studies, 7(2), 167-176.

Suleman, D., Ali, H., Nusraningrum, D., \& Ali, M.M.A. (2019), Perceived Ease of Use, Trust and Risk toward Attitude and Intention in Shopping for Online Fashion Products in Indonesia, Archives of Business Research, 7(4), 240-253, https://doi.org/10.14738/abr.74.6482.

Van Braak, J. (2004), Domains and determinants of university students' self-perceived computer competence, Computers \& Education, 43(3), 299-312.

Wu, S., \& Chen, J. (2014), Model of Green Consumption Behavior Constructed by the Theory of Planned Behavior, International Journal of Marketing Studies, 6(5). 


\section{References in Vietnamese}

Hoang Trong \& Chu Nguyen Mong Ngoc (2008), Research data analysis with SPSS, volume 2, Hong Duc.

Le Dinh Hac (2020), Development trend of non-cash payment in Vietnam, Online financial magazine.

Nguyen Dai Lai (2020), Current situation, trends and proposals for the development of non-cash payment methods, Financial and money market magazine.

Nguyen Thi Quynh Hoa (2020), The world's trend of developing card and electronic payment method and a recommendation for Vietnam, Trade Research Institute, Hawking Education Development Joint Stock Company.

\section{Appendix}

Appendix 1. Exploratory Factor Analysis (EFA) Results

\begin{tabular}{|c|c|c|c|c|c|c|c|c|}
\hline \multirow[t]{3}{*}{ Code } & \multirow[t]{3}{*}{ Items } & \multicolumn{7}{|c|}{ Rotated component matrix } \\
\hline & & \multicolumn{7}{|c|}{ Component } \\
\hline & & 1 & 2 & 3 & 4 & 5 & 6 & 7 \\
\hline PU & Perceived Usefulness & & & & & & & \\
\hline PU3 & The online payment system makes online shopping easier. & 0.511 & & & & & & \\
\hline PU4 & $\begin{array}{l}\text { The online payment system is more efficient than the } \\
\text { traditional payment method }\end{array}$ & 0.840 & & & & & & \\
\hline PU5 & $\begin{array}{l}\text { There are more choices when shopping online. (Goods, } \\
\text { suppliers, ...) }\end{array}$ & 0.729 & & & & & & \\
\hline PE & Perceived Ease of use & & & & & & & \\
\hline PE1 & $\begin{array}{l}\text { The structure and contents of the online payment are } \\
\text { straightforward }\end{array}$ & & 0.695 & & & & & \\
\hline PE2 & $\begin{array}{l}\text { The online payment procedure is flexible (in terms of time, } \\
\text { place, method) }\end{array}$ & & 0.746 & & & & & \\
\hline PE3 & $\begin{array}{l}\text { The online payment procedure is clear and easy to } \\
\text { understand }\end{array}$ & & 0.769 & & & & & \\
\hline PE4 & Learning to use the online payment system is easy for me & & 0.753 & & & & & \\
\hline PE5 & $\begin{array}{l}\text { The use of online payment system does not require my } \\
\text { mental effort }\end{array}$ & & 0.711 & & & & & \\
\hline PE6 & The online payment methods are diverse & & 0.651 & & & & & \\
\hline SN & Subjective Norm & & & & & & & \\
\hline SN1 & $\begin{array}{l}\text { The people I love support me to conduct online } \\
\text { transactions }\end{array}$ & & & 0.768 & & & & \\
\hline SN2 & $\begin{array}{l}\text { People close to me will agree with my implementation of } \\
\text { online transactions }\end{array}$ & & & 0.793 & & & & \\
\hline SN3 & $\begin{array}{l}\text { Feedbacks and reputation of the people I know motivate } \\
\text { me to make online transactions }\end{array}$ & & & 0.787 & & & & \\
\hline SN4 & $\begin{array}{l}\text { The pressure from my friends making online transactions } \\
\text { affects me in using it }\end{array}$ & & & 0.739 & & & & \\
\hline SN5 & $\begin{array}{l}\text { The online shopping community I visit regularly } \\
\text { encourages me to make more online transactions }\end{array}$ & & & 0.749 & & & & \\
\hline Tr & Trust & & & & & & & \\
\hline Tr1 & nerce website provides a reliable payment service & & & & 0.740 & & & \\
\hline $\operatorname{Tr} 2$ & $\begin{array}{l}\text { I believe in the security of the payment system when } \\
\text { making transactions }\end{array}$ & & & & 0.798 & & & \\
\hline $\operatorname{Tr} 3$ & $\begin{array}{l}\text { I have confidence in my system and trading support } \\
\text { process }\end{array}$ & & & & 0.790 & & & \\
\hline $\operatorname{Tr} 4$ & $\begin{array}{l}\text { The payment system has been verified by an independent } \\
\text { party }\end{array}$ & & & & 0.784 & & & \\
\hline Tr5 & The payment system has a reputable payment record & & & & 0.779 & & & \\
\hline $\mathbf{R i}$ & Risk & & & & & & & \\
\hline
\end{tabular}




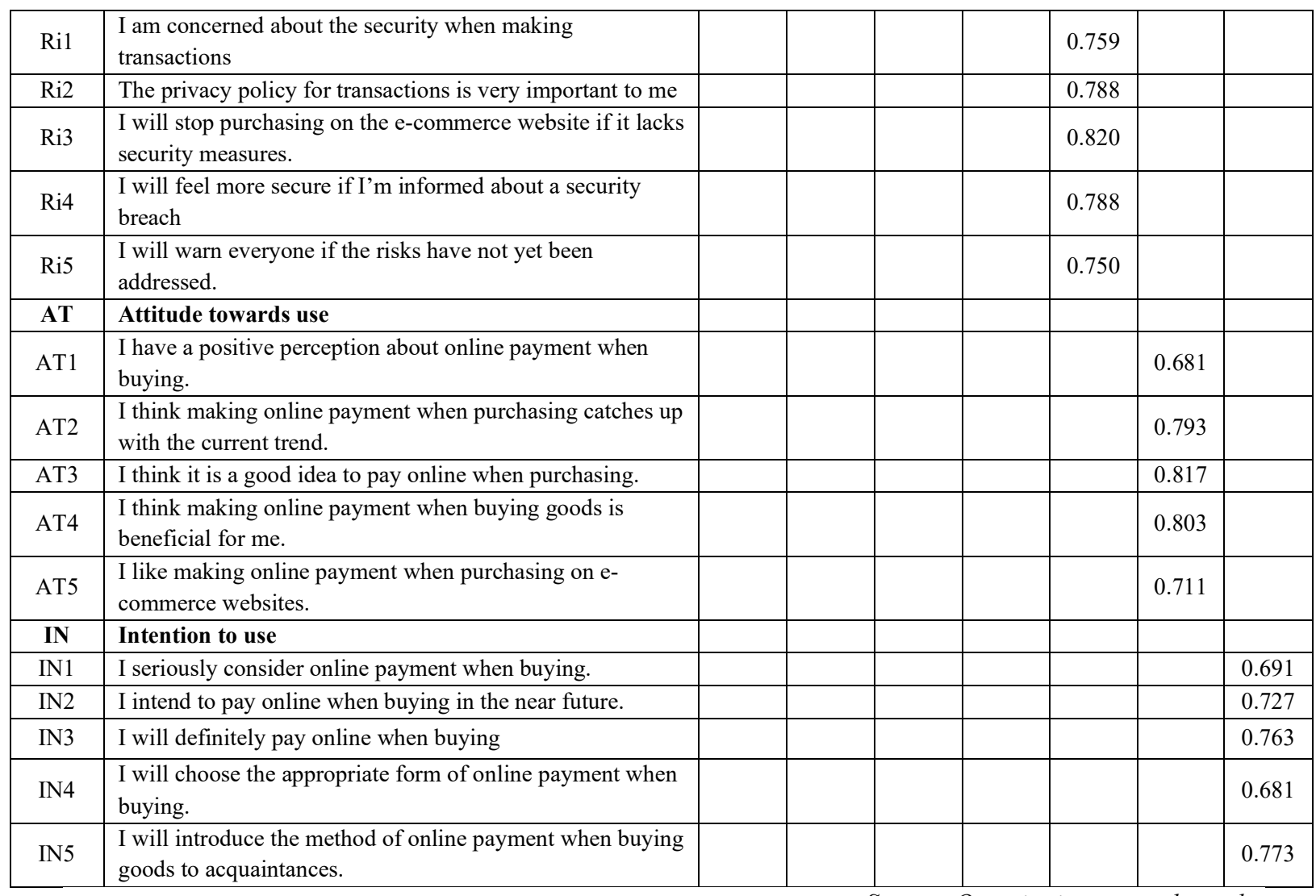

Source: Quantitative research results 